\title{
The Jurassic of Denmark and Greenland: key elements in the reconstruction of the North Atlantic Jurassic rift system
}

\author{
Finn Surlyk and Jon R. Ineson
}

\begin{abstract}
The Jurassic succession of Denmark is largely confined to the subsurface with the exception of exposures on the island of Bornholm in the Baltic Sea. In East Greenland, in contrast, the Jurassic is extensively exposed. Comparison of basin evolution in the two regions, which now occur on two separate plates, thus relies on highly different datasets. It is possible nevertheless to construct an integrated picture allowing testing of hypotheses concerning basin evolution, regional uplift, onset and climax of rifting, relative versus eustatic sea-level changes and sequence stratigraphic subdivision and correlation. On a smaller scale, it is possible to compare the signatures of sequence stratigraphic surfaces as seen on well logs, in cores and at outcrop and of sequences recognised and defined on the basis of very different data types.

Breakdown of the successions into tectonostratigraphic megasequences highlights the high degree of similarity in overall basin evolution and tectonic style. An important difference, however, lies in the timing. Major events such as late Early - Middle Jurassic uplift, followed by onset of rifting, basin reorganisation and rift climax were delayed in East Greenland relative to the Danish region. This has important implications both for regional reconstructions of the rift system and for the understanding and testing of classical sequence stratigraphic concepts involving eustatic versus tectonic controls of basin evolution and stratigraphy.
\end{abstract}

Keywords: Denmark, Greenland, Jurassic, correlation, parallel evolution

F.S., Geological Institute, University of Copenhagen, Geocenter Copenhagen, Øster Voldgade 10, DK-1350 Copenhagen K, Denmark. E-mail: finns@geo.geol.ku.dk

J.R.I., Geological Survey of Denmark and Greenland, Geocenter Copenhagen, Øster Voldgade 10, DK-1350 Copenhagen K, Denmark. E-mail: ji@geus.dk

The Jurassic of Denmark is mainly known from subsurface data including numerous boreholes and a dense net of seismic lines in the offshore areas. Exceptions to this include the island of Bornholm in the Baltic Sea and adjacent areas of Skåne, southern Sweden, where the Jurassic is exposed in many small outcrops. The Jurassic of Greenland, in contrast, can be studied in extensive outcrops and the succession forms the walls and tops of mountains and plateaus over wide areas. The two regions were once part of the same large-scale system of extensional basins in the Northwest European - North Atlantic region (Fig. 1), but are today located on two different plates separated by a thousand kilometres of ocean.

The aim of this introductory paper is to compare and contrast the stratigraphic evolution of the two regions based primarily on the detailed studies included in this book; the focus is on the timing and nature of tectonic events and on the overall stratigraphic trends. The goal is to provide a broad evolutionary framework for the Jurassic of Denmark and Greenland to set the scene for the succeeding papers. For comprehensive reviews of the North Atlantic Mesozoic rift system, the 
reader is referred to Ziegler (1988, 1990), Doré (1992), Doré et al. (1999), Skogseid et al. (2000) and Brekke et al. (2001).

\section{Sequence stratigraphy - a conceptual note}

Much of the research presented in this book is based on sequence stratigraphic analysis and it is pertinent in this introduction to comment briefly on the conceptual basis for these studies. As stressed by many workers (e.g. Carter et al. 1991; Posamentier \& James 1993; Miall 1997), sequence stratigraphy may be applied in two fundamentally different ways, either involving construction of age models based on correlation with the so-called global cycle chart of Haq et al. (1987) or lithology prediction based on the interpretation of cyclicity in the rock record (Posamentier \& James 1993). These two distinct paradigms were termed the 'globaleustasy paradigm' and the 'complexity paradigm' by Miall \& Miall (2001). It is significant that few of the authors of the individual studies presented here use the 'global-eustasy paradigm' but prefer the 'complexity' model which deals with the stratigraphic architecture and predictability of sequences and their components. Emphasis is on the recognition, interpretation and dating of key surfaces and on the geometry and environmental nature of successive systems tracts. There is, in contrast, little reference to 'global cycle charts' and to the potential use of sea-level curves as dating tools. Rather, the ages and significance of key surfaces and derived sea-level curves are used to construct robust genetic stratigraphies, to chart basin evolution and to highlight the importance of timing of tectonic events and pulses of sediment input. This approach is in marked contrast to that adopted by most authors in the compilation by de Graciansky et al. (1998) in which the 'global-eustasy paradigm' is prevalent.

\section{Tectonostratigraphy}

Subdivision of the Jurassic successions of both regions into tectonostratigraphic packages (sensu Surlyk 1991) shows that the tectonic evolution and corresponding stratigraphic signals are broadly similar, although the timing of the transition from pre-rift uplift to onset of rifting and of rift culmination appears to be delayed in East Greenland compared to the North Sea region. The sedimentary environments and facies are also rather similar for the successive tectonostratigraphic units. The early pre-rift succession (Rhaetian-Sinemurian) of East Greenland is wholly non-marine, however, contrasting with the marine Late Triassic - Early Jurassic record of much of the Danish region. Conversely, the AalenianCallovian early syn-rift sediments of the North Sea and the Danish Basin are more proximal and terrestriallydominated than the correlatives in East Greenland which are almost exclusively marine.

The investigated time interval includes the uppermost Triassic and the lowermost Cretaceous in order to cover a complete set of genetically related units. This stratigraphic interval in Denmark and Greenland can be broadly compared in terms of two megasequences, an Upper Triassic - Middle Jurassic pre-rift megasequence and a Middle Jurassic - lowermost Cretaceous syn-rift megasequence, separated by a regional uplift event (Fig. 2). Detailed correlation between the two regions allowing comparison of short-term sea-level cycles is not yet possible. The pre-rift biostratigraphy is based to a large extent on dinocysts (Poulsen \& Riding 2003, this volume), which are stratigraphically rather long ranging and commonly show different ranges in the two regions. Correlation by ammonites can only be done at a few levels, notably in the Pliensbachian. Dating of the syn-rift succession is based mainly on dinocysts in the North Sea - Danish Basin region but on ammonites supported by dinocysts in East Greenland (Callomon 2003, this volume; Surlyk 2003, this volume). Faunal provincialism was strongly developed for much of the Middle and Late Jurassic.

\section{Pre-rift megasequence}

In East Greenland, the Rhaetian - Early Bajocian time interval was characterised by regional subsidence following rift events in the Late Permian and Early Triassic (Surlyk 1990, 2003, this volume). The depositional basin was centred over Jameson Land and stratigraphic units have a more or less basinwide extent and sheet-like geometry, reflecting the relatively uniform subsidence and the absence of major faulting (Dam \& Surlyk 1995, 1998). In general, however, individual units are thickest in the basin centre.

A similar development is seen in Denmark, the Upper Triassic - Aalenian succession recording a phase of relatively uniform regional subsidence following rift events in the Late Carboniferous - Early Permian and the Early-Middle Triassic. The sedimentary record is fragmentary, however, as Lower Jurassic rocks are missing 


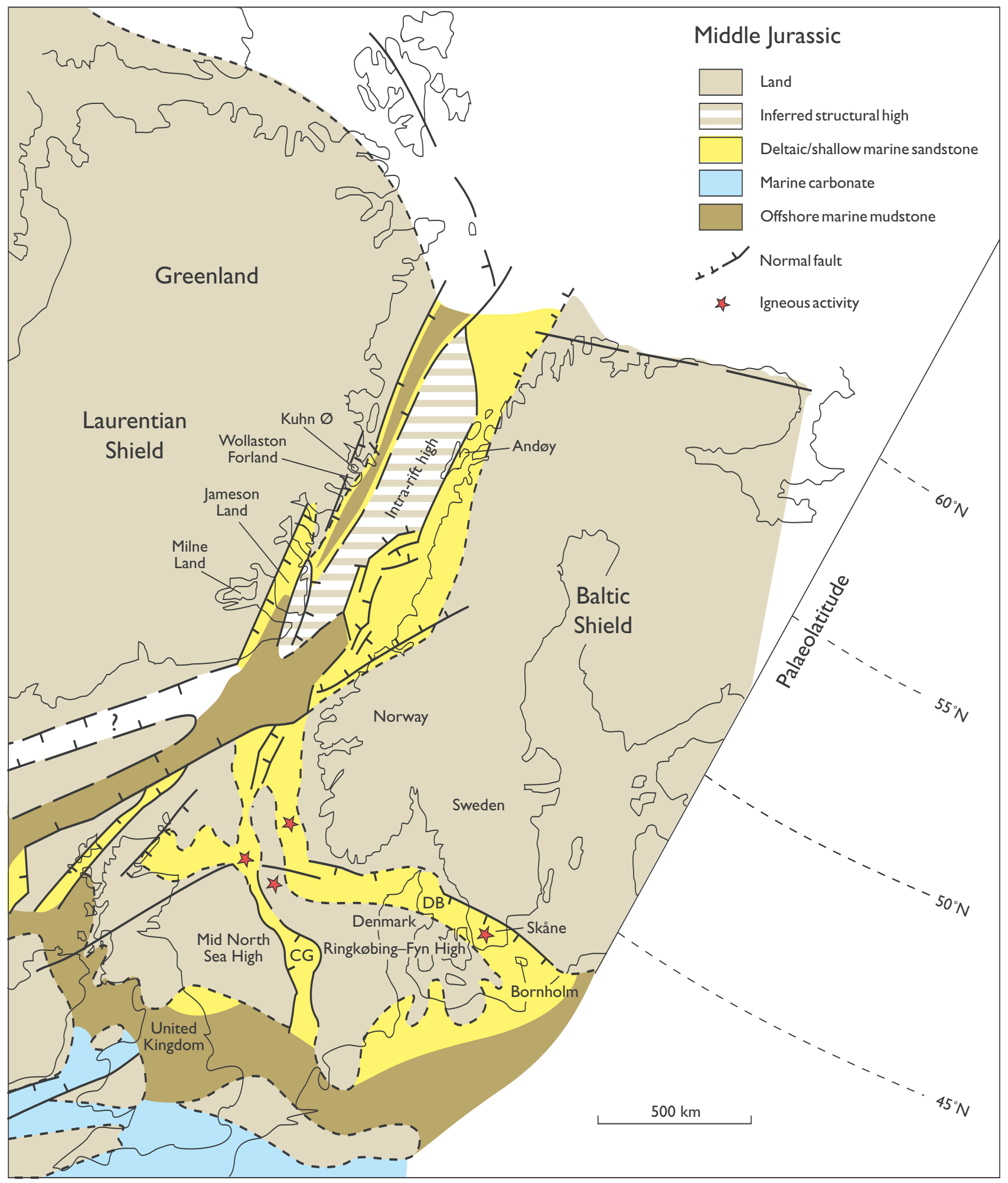

Fig. 1. Schematic Middle Jurassic reconstruction showing the regional tectonic elements and Jurassic seaways in the North Sea region and between Greenland and Norway. For location of intrabasinal structural elements (Danish Basin, Danish Central Graben) named in the text, the reader is referred to Michelsen et al. (2003, this volume). Map based on Ziegler (1988, 1990), Doré (1992) and Surlyk (2003, this volume). CG, Central Graben; DB, Danish Basin. 
from large parts of the area, particularly the Central Graben, due to erosion following early Middle Jurassic uplift (e.g. Ziegler 1990; Underhill \& Partington 1994; Andsbjerg et al. 2001; Andsbjerg \& Dybkjær 2003, this volume; Nielsen 2003, this volume). The erosional remnants, which are located marginal to and outside the main uplifted areas, are indicative of laterally extensive and sheet-like sedimentary packages, similar to those described from East Greenland. This architectural style is recorded, in particular, by the marine Lower Jurassic Fjerritslev Formation, which is recognised both in the Danish sector of the Central Graben and in the Danish Basin (Michelsen et al. 2003, this volume). Over much of the Danish area, the depositional environments and facies are more offshore marine and finer-grained than in the land-locked Jameson Land Basin of East Greenland although the paralic successions on Bornholm and in Skåne display alternating lacustrine, estuarine and shoreface deposits that closely resemble the Jameson Land succession and show a comparable overall transgressive trend (Ahlberg et al. 2003, this volume; Frandsen \& Surlyk 2003, this volume; Michelsen et al. 2003, this volume).

The pre-rift succession in East Greenland can be subdivided into a Rhaetian-Sinemurian fluvial-lacustrine part and a Pliensbachian - Early Bajocian estuarine - offshore marine part (Dam \& Surlyk 1995, 1998; Surlyk 2003, this volume). Although a similar gross subdivision, reflecting an overall transgressive trend, can be demonstrated in the Lower Jurassic of Denmark, the timing of the marine inundation of non-marine/paralic settings can only be compared in detail with that of East Greenland in the most proximal areas (Skagerrak-Kattegat Platform, Skåne, Bornholm). Here, the Rhaetian-Hettangian succession was deposited in terrestrial environments succeeded by paralic Sinemurian and offshore marine Pliensbachian conditions. In the Danish Central Graben and the axial parts of the Danish Basin, marine conditions were already established in Late Triassic - earliest Jurassic times (Fig. 2). A composite regressive event took place in the Danish Basin in the Rhaetian, corresponding broadly to a hiatus in the Danish Central Graben (Fig. 2); the subsequent Hettangian-Sinemurian period was a time of stepwise deepening and expansion of the open marine environment, reaching Bornholm in the latest Sinemurian (Surlyk et al. 1995; Nielsen 2003, this volume, fig. 31). Hence, inundation of the nonmarine Jameson Land Basin at the Sinemurian-Pliensbachian boundary was broadly coeval with a long-term maximum transgression in the Danish area (Fig. 2). In the Danish Basin, the Toarcian records the onset of re- gression and progressive basin restriction, heralding regional uplift and erosion and the reversion to terrestrial conditions in the Middle Jurassic.

A comparable phase of basin restriction in East Greenland, albeit somewhat later (latest Toarcian Aalenian), appears to be indicated by evidence of brackish water conditions in the lower part of the offshore marine Sortehat Formation (Dam \& Surlyk 1998; Koppelhus \& Hansen 2003, this volume). This event may be attributable to progressive tectonic isolation of the Jameson Land Basin due to regional uplift farther north.

Basin evolution in both East Greenland and Denmark was thus highly similar with regional subsidence by thermal contraction following rift events in the latest Palaeozoic and earliest Mesozoic. A marked transgressive trend characterised deposition in both areas; marine conditions were restricted to the axial parts of the seaways in the Late Triassic and earliest Jurassic, spreading to the basin margins (e.g. Skåne, Bornholm) and the most proximal depocentres (e.g. Jameson Land Basin) by the latest Sinemurian - Early Pliensbachian. Stepwise regression and basin restriction in the Danish Basin in the Middle-Late Toarcian probably resulted from progressive uplift of the Ringkøbing-Fyn High, heralding the regional mid-Jurassic uplift event (Nielsen 2003, this volume).

\section{Mid-Jurassic regional uplift and erosion}

In East Greenland, the Rhaetian - Lower Bajocian prerift megasequence is restricted to the Jameson Land Basin, which contains a relatively complete succession. The youngest strata beneath the unconformity that caps the megasequence are of Early Bajocian age based on dinocysts (Underhill \& Partington 1994; Koppelhus \& Hansen 2003, this volume) and supported by Sr-isotope data (M. Engkilde, personal communication 2000). A detailed ammonite zonation has been established for the shallow marine Pelion Formation overlying the unconformity but the ammonites are strictly boreal and the Bajocian-Bathonian interval cannot be directly correlated with European zonations. However, the immediate predecessor of the oldest of the boreal Middle Jurassic ammonites, Cranocephalites borealis, is the subgenus Defonticeras of the genus Sphaeroceras from the north-eastern Pacific which is confidently dated to the uppermost Lower Bajocian Stephanoceras humphriesianum Chronozone (Callomon 1985). The great resemblance of Sphaeroceras (Defonticeras) oblatum and $C$. borealis suggests that the age difference 
between them is small and the age of the $C$. borealis Zone and of the basal onlapping strata is thus early Late Bajocian. There is a short hiatus between the Sortehat and Pelion Formations and combined evidence from dating by Sr-isotopes, dinocysts and ammonites suggests that it covers an interval across the Lower-Upper Bajocian boundary.

The hiatus is associated with a complete change in basin configuration and drainage pattern marking the onset of rifting in East Greenland. The overlying deposits of the Pelion Formation and its correlatives show extensive onlap onto basin margins and northwards up the axis of the new rift (Alsgaard et al. 2003, this volume; Engkilde \& Surlyk 2003, this volume; Larsen et al. 2003, this volume). The base of this early syn-rift succession youngs to the north and onlaps progressively older rocks from Upper Triassic through Lower Triassic and Upper Permian to crystalline basement in a northwards direction (Surlyk 2003, this volume).

The absence of Lower Jurassic rocks north of Jameson Land has been interpreted to reflect large-scale, possibly domal, uplift of northern East Greenland in late Early Jurassic time (Surlyk 1977a, b; Surlyk et al. 1993). A similar situation is known from the Norwegian side of the rift complex where large areas were uplifted in late Early Jurassic time; the stratigraphy on Andøy on the conjugate margin of northern East Greenland thus shows the same development as in Wollaston Forland, i.e. crystalline basement draped by a thin veneer of Upper Palaeozoic carbonates is directly overlain by Middle Jurassic sandstones (Dalland 1981). The reality of Early Jurassic uplift to the north of Jameson Land originally suggested on stratigraphic grounds has recently been corroborated on the basis of apatite fission track thermochronology by Johnson \& Gallagher (2000). In contrast, the Jameson Land area shows no evidence of Early Jurassic uplift and cooling (Mathiesen et al. 2000). Data from the Norwegian shelf show that wide areas were uplifted in late Early Jurassic time (Doré 1992).

It has long been known that major uplift took place in the North Sea in late Early - early Middle Jurassic times (Whiteman et al. 1975; Hallam \& Sellwood 1976; Eynon 1981; Ziegler 1988; Underhill \& Partington 1993, 1994). The uplifted area is generally referred to as the 'midNorth Sea dome' and has been interpreted as having been caused by pre-rift heating and uplift followed by volcanism and rifting. The uplifted area underwent strong erosion and gradually deflated, being onlapped and subsequently flooded during Middle and Late Jurassic times. Underhill \& Partington $(1993,1994)$ demonstrated that the strata subcropping the erosional unconformity became gradually older approaching the centre of the uplift while the onlapping strata became younger in the same direction. More recent work has shown that the uplifted area was not a simple well-defined dome but involved the Ringkøbing-Fyn High, much of the Danish Basin and the Fennoscandian Border Zone (Nielsen 1995, 2003, this volume; Andsbjerg et al. 2001).

In the North Sea, the main unconformity is typically constrained to the mid-Aalenian in marginal areas. In the Sorgenfrei-Tornquist Zone of the Danish Basin, for example, Lower Aalenian strata both underlie and overlie the unconformity and, based on dinoflagellate data, the unconformity appears to lie within the upper levels of the lowermost Aalenian L. opalinum Chronozone (Nielsen 2003, this volume). As in East Greenland, however, the limitations of the biostratigraphic data should be acknowledged since dating of the dominantly terrestrial sediments of the strata overlying the unconformity in the North Sea is notoriously difficult.

Although the uplift and especially the onset of rifting and the associated radical basin reorganisation appear to have occurred earlier in the Danish region than in East Greenland, the main onlap phase onto the regional unconformity was broadly coeval, from the Late Bajocian to the Early Oxfordian (Underhill \& Partington 1993, 1994; Andsbjerg et al. 2001; Andsbjerg \& Dybkjær 2003, this volume; Nielsen 2003, this volume; Surlyk 2003, this volume). It is noteworthy that this northwards delay in initial uplift from the Danish region to East Greenland is mirrored passing southwards from the Danish area to the Dutch sector of the Central Graben where the uplift - rift onset hiatus spans the mid-Bajocian - mid-Callovian (Herngreen et al. 2003, this volume).

Regional uplift, erosion and subsequent subsidence, onset of rifting and onlap of the previously uplifted area thus took place in both East Greenland and Denmark in late Early - early Middle Jurassic times. A common cause can be envisaged for both regions but the succession of events seems to be delayed in East Greenland compared to the Central North Sea.

\section{Syn-rift megasequence}

The regional uplift event at the Early-Middle Jurassic transition was succeeded by the onset of a long-term rifting episode, which began in the Middle Jurassic, peaked in the Late Jurassic and persisted into the earliest Cretaceous. Rifting was not continuous but comprised phases of more intense rifting and block rotation 


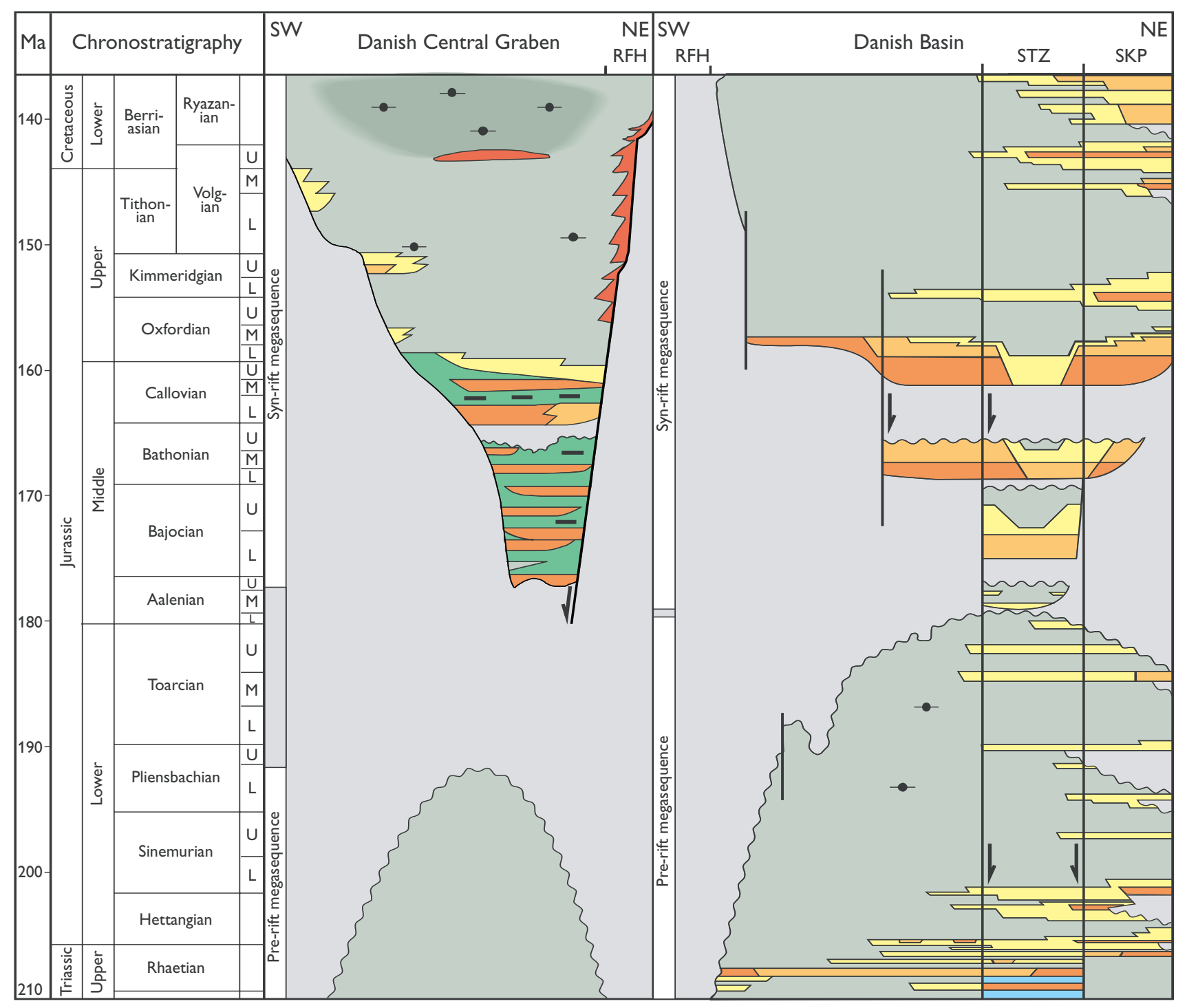

alternating with more tranquil periods of regional subsidence. The syn-rift succession can be subdivided into a number of tectonostratigraphic units marked by rift events followed by more gradual subsidence. Seven regional tectonostratigraphic sequences have been recognised for the Aalenian-Valanginian stratigraphic interval in the Central and Northern North Sea (UK and Norwegian sectors) by Rattey \& Hayward (1993); the evolution of the Danish Central Graben in the Aalenian-Ryazanian described by Andsbjerg \& Dybkjær (2003, this volume) is broadly compatible with the regional framework of Rattey \& Hayward (1993) although megasequences were not defined in the Danish Central Graben study.

The seven North Sea tectonostratigraphic sequences of Rattey \& Hayward (1993) are equivalent to six sequences for the correlative interval in East Greenland
(Surlyk \& Noe-Nygaard 2000; Surlyk 2003, this volume). The main difference between the two regions seems to be the delayed onset and culmination of rifting in East Greenland compared to the North Sea and the apparent lack of a tectonostratigraphic sequence boundary roughly at the Oxfordian-Kimmeridgian boundary in East Greenland. Otherwise the sequences correspond broadly to each other in timing and stratigraphic development, and it is not always clear if the differences, i.e. the slightly older positions of the boundaries in the North Sea, are real. They may also reflect dating by ammonites in Greenland and by dinocysts in the North Sea, respectively, and uncertainties in the correlation between the two zonations. It has been noted by a few workers that the base of dinocyst zones tend to occur at progressively higher levels compared to ammonite zone boundaries in a North Sea - East Greenland - North Greenland tran- 


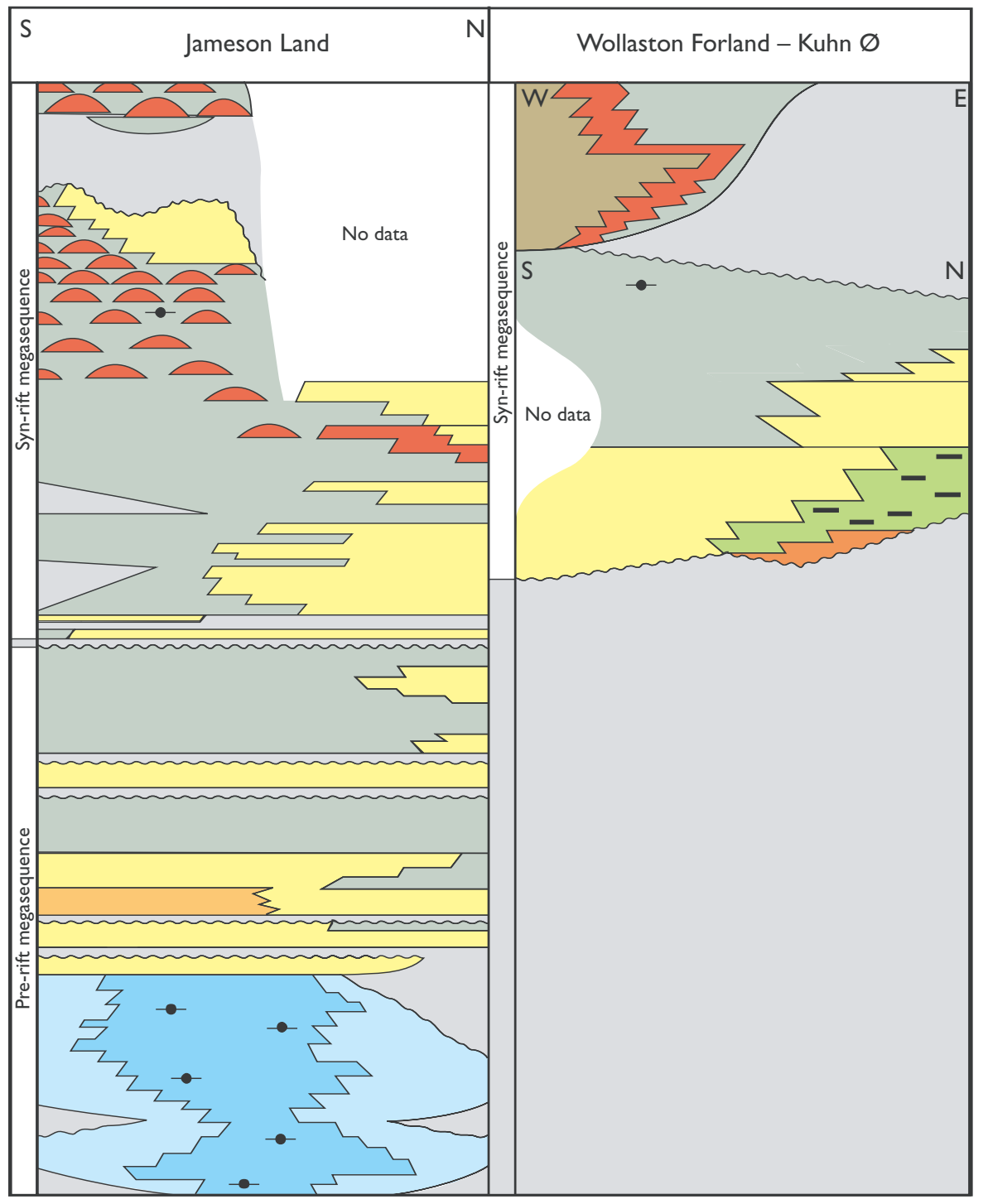

Lacustrine deltas, sand-dominated

Lacustrine mudstones

Alluvial/delta plain - paralic, sand-dominated

Fluvial and estuarine sandstones, conglomerates

Floodplain mudstones

Estuarine/lagoonal sandstones, heteroliths, mudstones and coal beds

Shallow marine sandstones

Offshore/basinal mudstones, heteroliths

Organic-rich offshore/basinal mudstones

Deep marine sandstones

Deep marine conglomerates

Hiatus/condensed

- Coal

$\rightarrow$ Source rock

Fig. 2. Chronostratigraphic scheme of the uppermost Triassic - lowermost Cretaceous of the Danish Central Graben, the Danish Basin and East Greenland showing the main lithologies, depositional environments and tectonostratigraphic sequences. Simplified from Andsbjerg \& Dybkjær (2003, this volume), Nielsen (2003, this volume) and Surlyk (2003, this volume); time-scale after Gradstein et al. (1994). RFH, Ringkøbing-Fyn High; SKP, Skagerrak-Kattegat Platform; STZ, Sorgenfrei-Tornquist Zone.

sect (Smelror 1993; S. Piasecki, personal communication 2002). The northwards younging of tectonostratigraphic boundaries may thus be real, possibly reflecting progressive northward propagation of the rift system as suggested by Surlyk \& Clemmensen (1983), or apparent, reflecting correlation problems at a time of marked ammonite provinciality or northward migration of indicator dinocysts with respect to the more finely-tuned ammonite zonation that forms the basis for Jurassic chronostratigraphy.

Early syn-rift sedimentation (Late Aalenian - Bajocian) in the Danish Basin and the Danish Central Graben was confined to narrow subsiding grabens and the succession is probably incomplete with a number of inferred unconformities within the Bajocian-Bathonian part. It is noteworthy that a prominent unconformity is recorded in the uppermost Bathonian of the northern Danish
Central Graben, recording a marked shift in subsidence patterns during early rifting (Andsbjerg 2003, this volume). Although loosely constrained biostratigraphically, a hiatal surface is also inferred at this level in the Danish Basin (Fig. 2; Nielsen 2003, this volume). This event is not detected in the East Greenland sedimentary record where the Bathonian-Callovian transition is characterised by transgression and progressive backstepping of sedimentary systems (Fig. 2); minor hiatuses are recorded at this stratigraphic level but these resulted from condensation and non-deposition in offshore settings.

The syn-rift successions of Denmark and East Greenland are suggestive of a northward younging diachroneity of rift phases. The rift climax occurred in the Early Oxfordian - middle Middle Volgian in the Danish sector of the Central Graben, albeit with an important lull in the Late Kimmeridgian characterised 
by regression and shoreface progradation (Andsbjerg \& Dybkjær 2003, this volume; Johannessen 2003, this volume; Møller \& Rasmussen 2003, this volume). The late Middle and Late Volgian saw a general waning in rift activity in the Danish Central Graben resulting in the development of more symmetrical sub-basins, associated with a general reduction in the overall sedimentation rate. Indeed, the Upper Volgian - Lower Ryazanian in the Central Graben is characterised by a relatively condensed stratigraphic package of organic-rich 'hot shales', associated locally with basin floor sands (Donovan et al. 1993; Ineson et al. 2003, this volume)

An Oxfordian - Early Volgian rift climax seems to be applicable to the Jameson Land Basin at the southern end of the East Greenland rift basin where chaotic deepwater sandstones of the Upper Oxfordian - Lower Volgian Hareelv Formation mark the rift climax (Surlyk \& Noe-Nygaard 2001; Surlyk 2003, this volume). It was succeeded by rapid progradation and basin infill in Middle and Late Volgian times as rift activity waned. In Wollaston Forland at the northern end of the rift basin, however, the Late Oxfordian - Early Volgian was characterised by gentle block tilting, whereas the rift climax accompanied by strong block tilting took place in the Middle Volgian.

Taken at face value, therefore, the stratigraphic synrift histories of the two regions are broadly similar but the main events appear to have started earlier in the south.

\section{Conclusions}

Unravelling the complexities of the Jurassic rifted seaway in the North Atlantic region continues to be a subject of major research interest, not least due to the hydrocarbon potential of Jurassic basins on both sides of the Atlantic Ocean. The basins of East Greenland and Denmark represent important pieces in this jigsaw puzzle and the studies reported in the following papers will help to further constrain regional models of rift development, and to better understand Jurassic stratigraphic development in general. Comparison of the Jurassic evolution of these areas makes it possible to construct an integrated picture of the long, relatively narrow seaways, allowing testing of ideas concerning basin evolution, domal versus regional uplift, and timing of the onset and climax of rifting. In addition to this regional perspective, parallel research into the Jurassic of the East Greenland and Danish basins allows comparison of the signatures of sequence stratigraphic surfaces as seen on well logs, in cores and at outcrop, and of sequences recognised and defined on the basis of very different data types. Furthermore, experience gleaned from the extensive outcrops of East Greenland aids interpretation of restricted outcrops on Bornholm and in Skåne and allows them to be placed within a regional framework.

The tectonostratigraphic summary presented above shows that the main tectonic events and stratigraphic trends in East Greenland, Denmark and adjacent areas are highly similar but apparently somewhat out of phase for the syn-rift successions (Fig. 3). The Rhaetian - Early Jurassic was characterised by regional subsidence following late Palaeozoic and early Mesozoic rift events and the detailed stratigraphic signature reflects relative sealevel changes superimposed on a long-term sea-level rise.

Major regional uplift heralding the onset of rifting took place broadly at the Early-Middle Jurassic boundary and the uplifted areas underwent marked erosion. Subsequent subsidence began in the Aalenian in the North Sea and in the Late Bajocian in East Greenland concomitant with the onset of rifting, resulting in major regional onlap and transgression. Continued relative sea-level rise, reflecting the early rifting, took place in the Bathonian; deltas and shallow marine sandy systems were drowned almost everywhere by the end of the Callovian. Rifting culminated in Early Oxfordian - Volgian times with major block tilting and deposition of fault-scarp aprons and basin-floor fans. The rift climax was delayed in northern East Greenland compared to areas further south.

The timing and style of tectonic events thus exerted the main control on the long-term trends in stratigraphic evolution. In the Early Jurassic, however, relative sealevel changes that were unrelated to local tectonics seem to have exerted the main control on the depositional motifs (Dam \& Surlyk 1995, 1998; Andsbjerg \& Dybkjær 2003, this volume; Nielsen 2003, this volume; Surlyk 2003, this volume). The Late Jurassic deepening and transgressive trend, on the other hand, appears to reflect accelerated regional subsidence, increased tilting of fault blocks, eustatic sea-level rise or a combination of these factors, and isolation of the dominant control is difficult without comparison with successions on other lithospheric plates.

\section{Acknowledgements}

This introductory paper is based mainly on the detailed studies reported in this book; we acknowledge the authors and thank Peter R. Dawes, Peter N. Johannessen, Michael Larsen and Lars H. Nielsen for useful comments. 


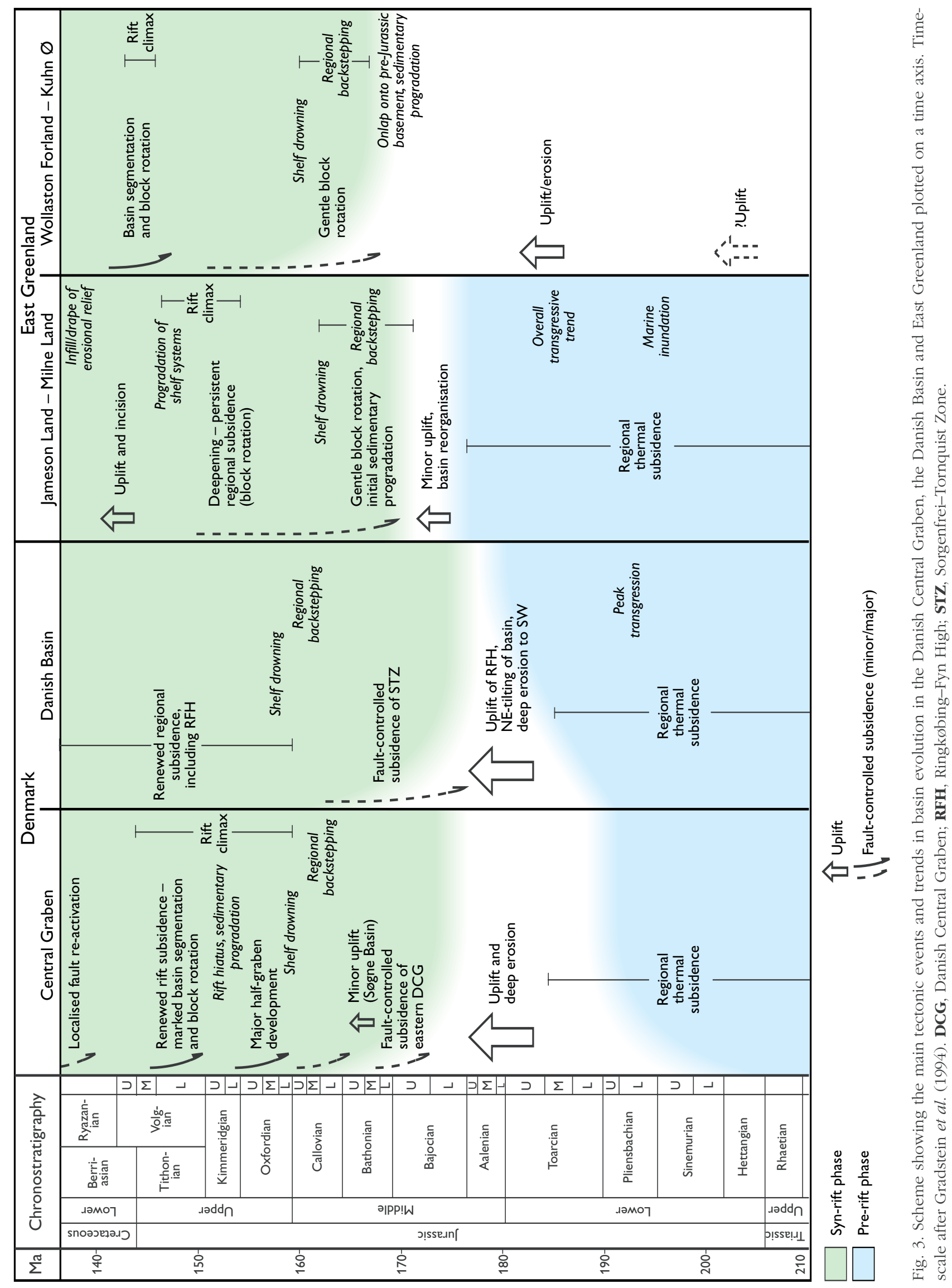




\section{References}

Ahlberg, A., Sivhed, U. \& Erlström, M. 2003: The Jurassic of Skåne, southern Sweden. In: Ineson, J.R. \& Surlyk, F. (eds): The Jurassic of Denmark and Greenland. Geological Survey of Denmark and Greenland Bulletin 1, 527-541 (this volume).

Alsgaard, P.C., Felt, V.L., Vosgerau, H. \& Surlyk, F. 2003: The Jurassic of Kuhn $\varnothing$, North-East Greenland. In: Ineson, J.R. \& Surlyk, F. (eds): The Jurassic of Denmark and Greenland. Geological Survey of Denmark and Greenland Bulletin 1, 865-892 (this volume).

Andsbjerg, J. 2003: Sedimentology and sequence stratigraphy of the Bryne and Lulu Formations, Middle Jurassic, northern Danish Central Graben. In: Ineson, J.R. \& Surlyk, F. (eds): The Jurassic of Denmark and Greenland. Geological Survey of Denmark and Greenland Bulletin 1, 301-347 (this volume).

Andsbjerg, J. \& Dybkjær, K. 2003: Sequence stratigraphy of the Jurassic of the Danish Central Graben. In: Ineson, J.R. \& Surlyk, F. (eds): The Jurassic of Denmark and Greenland. Geological Survey of Denmark and Greenland Bulletin 1, 265-300 (this volume).

Andsbjerg, J., Nielsen, L.H., Johannessen, P.N. \& Dybkjær, K. 2001: Divergent development of two neighbouring basins following the Jurassic North Sea doming event: the Danish Central Graben and the Norwegian-Danish Basin. In: Martinsen, O.J. \& Dreyer, T. (eds): Sedimentary environments offshore Norway - Palaeozoic to Recent. Norwegian Petroleum Society (NPF) Special Publication 10, 175-197.

Brekke, H., Sjulstad, H.I., Magnus, C. \& Williams, R.W. 2001: Sedimentary environments offshore Norway - an overview. In: Martinsen, O.J. \& Dreyer, T. (eds): Sedimentary environments offshore Norway - Palaeozoic to Recent. Norwegian Petroleum Society (NPF) Special Publication 10, 7-37.

Callomon, J.H. 1985: The evolution of the Jurassic ammonite family Cardioceratidae. In: Cope, J.C.W. \& Skelton, P.W. (eds): Evolutionary case histories from the fossil record. Special Papers in Palaeontology 33, 49-90. London: Palaeontological Association.

Callomon, J.H. 2003: The Middle Jurassic of western and northern Europe: its subdivisions, geochronology and correlations. In: Ineson, J.R. \& Surlyk, F. (eds): The Jurassic of Denmark and Greenland. Geological Survey of Denmark and Greenland Bulletin 1, 61-73 (this volume).

Carter, R.M., Abbott, S.T., Fulthorpe, C.S., Haywick, D.W. \& Henderson, R.A. 1991: Application of global sea-level and sequence-stratigraphic models in southern hemisphere Neogene strata from New Zealand. In: MacDonald, D.I.M. (ed.): Sedimentation, tectonics and eustasy. International Association of Sedimentologists Special Publication 12, 41-65.

Dalland, A. 1981: Mesozoic sedimentary succession at Andøy, northern Norway, and relation to structural development of the North Atlantic area. In: Kerr, J.W. \& Fergusson, A.J. (eds): Geology of the North Atlantic Borderlands. Canadian Society of Petroleum Geologists Memoir 7, 563-584.

Dam, G. \& Surlyk, F. 1995: Sequence stratigraphic correlation of Lower Jurassic shallow marine and paralic successions across the Greenland-Norway seaway. In: Steel, R.J. et al. (eds):
Sequence stratigraphy on the Northwest European margin. Norwegian Petroleum Society (NPF) Special Publication 5, 483-499.

Dam, G. \& Surlyk, F. 1998: Stratigraphy of the Neill Klinter Group; a Lower - lower Middle Jurassic tidal embayment succession, Jameson Land, East Greenland. Geology of Greenland Survey Bulletin 175, 80 pp.

de Graciansky, P.-C., Hardenbol, J., Jacquin, T. \& Vail, P.R. (eds) 1998: Mesozoic and Cenozoic sequence stratigraphy of European basins. SEPM (Society for Sedimentary Geology) Special Publication 60, 481-506.

Donovan, A.D., Djakic, A.W., Ioannides, N.S., Garfield, T.R. \& Jones, C.R. 1993: Sequence stratigraphic control on Middle and Upper Jurassic reservoir distribution within the UK Central North Sea. In: Parker, J.R. (ed.): Petroleum geology of Northwest Europe: proceedings of the 4th conference, 251-269. London: Geological Society

Doré, A.G. 1992: Synoptic palaeogeography of the Northeast Atlantic Seaway: Late Permian to Cretaceous. In: Parnell, J. (ed.): Basins on the Atlantic seaboard: petroleum geology, sedimentology and basin evolution. Geological Society Special Publication (London) 62, 421-446.

Doré, A.G., Lundin, E.R., Jensen, L.N., Birkeland, Ø., Eliassen, P.E. \& Fichler, C. 1999: Principal tectonic events in the evolution of the northwest European Atlantic margin. In: Fleet, A.J. \& Boldy, S.A.R. (eds): Petroleum geology of Northwest Europe: proceedings of the 5th conference, 41-61. London: Geological Society.

Engkilde, M. \& Surlyk, F. 2003: Shallow marine syn-rift sedimentation: Middle Jurassic Pelion Formation, Jameson Land, East Greenland. In: Ineson, J.R. \& Surlyk, F. (eds): The Jurassic of Denmark and Greenland. Geological Survey of Denmark and Greenland Bulletin 1, 813-863 (this volume)

Eynon, G. 1981: Basin development and sedimentation in the Middle Jurassic of the northern North Sea. In: Illing, L.V. \& Hobson, G.D. (eds): Petroleum geology of the continental shelf of North-West Europe: proceedings of the 2nd conference, 196-204. London: Heyden \& Son Ltd.

Frandsen, N. \& Surlyk, F. 2003: An offshore transgressive-regressive mudstone-dominated succession from the Sinemurian of Skåne, Sweden. In: Ineson, J.R. \& Surlyk, F. (eds): The Jurassic of Denmark and Greenland. Geological Survey of Denmark and Greenland Bulletin 1, 543-554 (this volume).

Gradstein, F.M., Agterberg, F.P., Ogg, J.G., Hardenbol, J., van Veen, P., Thierry, J. \& Huang, Z. 1994: A Mesozoic time scale. Journal of Geophysical Research 99, 24051-24074.

Hallam, A. \& Sellwood, B.W. 1976: Middle Mesozoic sedimentation in relation to tectonics in the British area. Journal of Geology 84, 301-321.

Haq, B.U., Hardenbol, J. \& Vail, P.R. 1987: Chronology of fluctuating sea levels since the Triassic. Science 235, 1156-1167.

Herngreen, G.F.W., Kouwe, W.F.P. \& Wong, T.E. 2003: The Jurassic of the Netherlands. In: Ineson, J.R. \& Surlyk, F. (eds): The Jurassic of Denmark and Greenland. Geological Survey of Denmark and Greenland Bulletin 1, 217-229 (this volume).

Ineson, J.R., Bojesen-Koefoed, J.A., Dybkjær, K. \& Nielsen, L.H. 2003: Volgian-Ryazanian 'hot shales' of the Bo Member 
(Farsund Formation) in the Danish Central Graben, North Sea: stratigraphy, facies and geochemistry. In: Ineson, J.R. \& Surlyk, F. (eds): The Jurassic of Denmark and Greenland. Geological Survey of Denmark and Greenland Bulletin 1, 403-436 (this volume).

Johannessen, P.N. 2003: Sedimentology and sequence stratigraphy of paralic and shallow marine Upper Jurassic sandstones in the northern Danish Central Graben. In: Ineson, J.R. \& Surlyk, F. (eds): The Jurassic of Denmark and Greenland. Geological Survey of Denmark and Greenland Bulletin 1, 367-402 (this volume).

Johnson, C. \& Gallagher, K. 2000: A preliminary Mesozoic and Cenozoic denudation history of the North East Greenland onshore margin. Global and Planetary Change 24, 261-274.

Koppelhus, E.B. \& Hansen, C.F. 2003: Palynostratigraphy and palaeoenvironment of the Middle Jurassic Sortehat Formation (Neill Klinter Group), Jameson Land, East Greenland. In: Ineson, J.R. \& Surlyk, F. (eds): The Jurassic of Denmark and Greenland. Geological Survey of Denmark and Greenland Bulletin 1, 777-811 (this volume).

Larsen, M., Piasecki, S. \& Surlyk, F. 2003: Stratigraphy and sedimentology of a basement-onlapping shallow marine sandstone succession, the Charcot Bugt Formation, Middle-Upper Jurassic, East Greenland. In: Ineson, J.R. \& Surlyk, F. (eds): The Jurassic of Denmark and Greenland. Geological Survey of Denmark and Greenland Bulletin 1, 893-930 (this volume).

Mathiesen, A., Bidstrup, T. \& Christiansen, F.G. 2000: Denudation and uplift history of the Jameson Land Basin, East Greenland - constrained from maturity and apatite fission track data. Global and Planetary Change 24, 275-301.

Miall, A.D. 1997: The geology of stratigraphic sequences, 433 pp. Berlin: Springer Verlag.

Miall, A.D. \& Miall, C.E. 2001: Sequence stratigraphy as a scientific enterprise: the evolution and persistence of conflicting paradigms. Earth-Science Reviews 54, 321-348.

Michelsen, O., Nielsen, L.H., Johannessen, P.N., Andsbjerg, J. \& Surlyk, F. 2003: Jurassic lithostratigraphy and stratigraphic development onshore and offshore Denmark. In: Ineson, J.R. \& Surlyk, F. (eds): The Jurassic of Denmark and Greenland. Geological Survey of Denmark and Greenland Bulletin 1, 147-216 (this volume)

Møller, J.J. \& Rasmussen, E.S. 2003: Middle Jurassic - Early Cretaceous rifting of the Danish Central Graben. In: Ineson, J.R. \& Surlyk, F. (eds): The Jurassic of Denmark and Greenland. Geological Survey of Denmark and Greenland Bulletin 1, 247-264 (this volume).

Nielsen, L.H. 1995: Genetic stratigraphy of Upper Triassic - Middle Jurassic deposits of the Danish Basin and Fennoscandian Border Zone 2, 3, 162 pp. Unpublished Ph.D. thesis, University of Copenhagen, Denmark.

Nielsen, L.H. 2003: Late Triassic - Jurassic development of the Danish Basin and the Fennoscandian Border Zone, southern Scandinavia. In: Ineson, J.R. \& Surlyk, F. (eds): The Jurassic of Denmark and Greenland. Geological Survey of Denmark and Greenland Bulletin 1, 459-526 (this volume).

Posamentier, H.W. \& James, D.P. 1993: An overview of sequencestratigraphic concepts: uses and abuses. In: Posamentier, H.W. et al. (eds): Sequence stratigraphy and facies associations. International Association of Sedimentologists Special Publication 18, 3-18.

Poulsen, N.E. \& Riding, J.B. 2003: The Jurassic dinoflagellate cyst zonation of Subboreal Northwest Europe. In: Ineson, J.R. \& Surlyk, F. (eds): The Jurassic of Denmark and Greenland. Geological Survey of Denmark and Greenland Bulletin 1, 115-144 (this volume).

Rattey, R.P. \& Hayward, A.B. 1993: Sequence stratigraphy of a failed rift system: the Middle Jurassic to Early Cretaceous basin evolution of the Central and Northern North Sea. In: Parker, J.R. (ed.): Petroleum geology of Northwest Europe: proceedings of the 4th conference, 215-249. London: Geological Society.

Skogseid, J., Planke, S., Faleide, J.A., Pedersen, T., Eldholm, O. \& Neverdal, F. 2000: NE Atlantic continental rifting and volcanic margin formation. In: Nøttvedt, A. (ed.): Dynamics of the Norwegian margin. Geological Society Special Publication (London) 167, 295-326.

Smelror, M. 1993: Biogeography of Bathonian to Oxfordian (Jurassic) dinoflagellates: Arctic, NW Europe and circumMediterranean regions. Palaeogeography, Palaeoclimatology, Palaeoecology 102, 121-160.

Surlyk, F. 1977a: Mesozoic faulting in East Greenland. In: Frost, R.T.C. \& Dikkers, A.J. (eds): Fault tectonics in NW Europe. Geologie en Mijnbouw 56, 311-327.

Surlyk, F. 1977b: Stratigraphy, tectonics and palaeogeography of the Jurassic sediments of the areas north of Kong Oscars Fjord, East Greenland. Bulletin Grønlands Geologiske Undersøgelse 123, 56 pp.

Surlyk, F. 1990: Timing, style and sedimentary evolution of Late Palaeozoic - Mesozoic extensional basins of East Greenland. In: Hardman, R.F.P. \& Brooks, J. (eds): Tectonic events responsible for Britain's oil and gas reserves. Geological Society Special Publication (London) 55, 107-125.

Surlyk, F. 1991: Tectonostratigraphy of North Greenland. In: Peel, J.S. \& Sønderholm, M. (eds): Sedimentary basins of North Greenland. Bulletin Grønlands Geologiske Undersøgelse 160, 25-47.

Surlyk, F. 2003: The Jurassic of East Greenland: a sedimentary record of thermal subsidence, onset and culmination of rifting. In: Ineson, J.R. \& Surlyk, F. (eds): The Jurassic of Denmark and Greenland. Geological Survey of Denmark and Greenland Bulletin 1, 659-722 (this volume).

Surlyk, F. \& Clemmensen, L.B. 1983: Rift propagation and eustacy as controlling factors during Jurassic inshore and shelf sedimentation in northern East Greenland. Sedimentary Geology 34, 119-143.

Surlyk, F. \& Noe-Nygaard, N. 2000: Jurassic sequence stratigraphy of East Greenland. In: Hall, R.L. \& Smith, P.L. (eds) Advances in Jurassic research 2000. Proceedings of the 5th International Symposium on the Jurassic System. GeoResearch Forum 6, 357-366.

Surlyk, F. \& Noe-Nygaard, N. 2001: Sand remobilisation and intrusion in the Upper Jurassic Hareelv Formation of East Greenland. In: Surlyk, F. \& Håkansson, E. (eds): Oscar volume. Bulletin of the Geological Society of Denmark 48, 169-188.

Surlyk, F., Dam, G. \& Noe-Nygaard, N. 1993: High and low 
resolution sequence stratigraphy in lithological prediction examples from around the northern North Atlantic. In: Parker, J.R. (ed.): Petroleum Geology of Northwest Europe: proceedings of the 4th conference, 199-214. London: Geological Society.

Surlyk, F., Arndorff, L., Hamann, N.-E., Hamberg, L., Johannessen, P.N., Koppelhus, E.B., Nielsen, L.H., Noe-Nygaard, N., Pedersen, G.K. \& Petersen, H.I. 1995: High-resolution sequence stratigraphy of a Hettangian-Sinemurian paralic succession, Bornholm, Denmark. Sedimentology 42, 323-354.

Underhill, J.R. \& Partington, M.A. 1993: Jurassic thermal doming and deflation in the North Sea: implications of the sequence stratigraphic evidence. In: Parker, J.R. (ed.): Petroleum Geology of Northwest Europe: proceedings of the 4th conference, 337-345. London: Geological Society.

Underhill, J.R. \& Partington, M.A. 1994: Use of genetic sequence stratigraphy in defining and determining a regional tectonic control on the 'mid-Cimmerian Unconformity' - implications for North Sea basin development and the global sea-level chart. In: Weimer, P. \& Posamentier, H.W. (eds): Siliciclastic sequence stratigraphy: recent developments and applications. American Association of Petroleum Geologists Memoir 58, 449-484.

Whiteman, A.J., Rees, G., Naylor, D. \& Pegrum, R.M. 1975: North Sea troughs and plate tectonics. Norges Geologiske Undersøkelse 316, 137-161.

Ziegler, P.A. 1988: Evolution of the Arctic - North Atlantic and the western Tethys. American Association of Petroleum Geologists Memoir 43, 198 pp.

Ziegler, P.A. 1990: Geological atlas of western and central Europe, 2nd edition, 239 pp. Amsterdam: Elsevier for Shell Internationale Petroleum Maatschappij. 